\title{
Evaluation of Public Weather Services by Users in the Formal Services Sector in Accra, Ghana
}

\author{
Kwabena Asomanin Anaman, Ruth Quaye, Evelyn Amankwah \\ Economics Division, Institute of Statistical, Social and Economic Research, University of Ghana, Accra, Ghana \\ Email: kwabenaasomanin@hotmail.com, kanaman@ug.edu.gh, ruthquay@gmail.com, evelyn.amankwah@gmail.com
}

How to cite this paper: Anaman, K.A., Quaye, R. and Amankwah, E. (2017) Evaluation of Public Weather Services by Users in the Formal Services Sector in Accra, Ghana. Modern Economy, 8, 921-945. https://doi.org/10.4236/me.2017.87065

Received: June 28, 2017

Accepted: July 23, 2017

Published: July 26, 2017

Copyright $\odot 2017$ by authors and Scientific Research Publishing Inc. This work is licensed under the Creative Commons Attribution International License (CC BY 4.0).

http://creativecommons.org/licenses/by/4.0/ (c) (i) Open Access

\begin{abstract}
We undertook a study that evaluated the public weather services used by people working in the formal services sector of the Ghana based in Accra, the capital city of Ghana. The study employed randomly-sampling survey technique to request information from 102 respondents on their use of services and information produced by the Ghana Meteorological Agency (GMet), the country's official producer and archival of meteorological data, information, products and services. The results of the analysis of survey data indicated that virtually all the respondents used public weather services produced by GMet. The users generally considered the quality of the public weather services to be of moderate quality. Using the contingent valuation method to ascertain the economic value of public weather services, $87.7 \%$ of the respondents were prepared to pay for the public weather services rather than be without them. The average WTP per person per month was 16.67 Ghana cedis per month or 200.04 Ghana cedis per year or 51.96 United States dollars per year. The aggregate economic value, based on only the users of public weather services in the formal services sector of Accra, who constitute just about $2.1 \%$ of the total work force of Ghana, is over four times the value of the annual budget provided by the Government of Ghana to GMet in 2016. Users in the formal services sector wanted GMet to produce more locality-specific weather forecasts and services with advance warning times. Further the information from the Agency needs to be distributed and publicised by the mass media through radio and television including the emerging and fast growing local languagebased mass media on hourly basis rather than the current system where they are supplied to the general public once a day via the evening television news through the English-language radio and TV channels.
\end{abstract}

\section{Keywords}

Contingent Valuation, Environmental Economics, Ghana, Ghana Meteorological Agency, Meteorological Services, Public Weather Services, Resource Economics 


\section{Country Overview, Brief History and Political Economy of Ghana}

Ghana is an English-speaking country in West Africa with a population of about 29 million (mid-2017 estimate) based on projections from the 2010 Population and Housing Census [1]. It is a unitary state divided into 10 politically administrative regions, 216 districts and 275 electoral constituencies. Ghana was originally named Gold Coast by European nation-state powers due to the vast amounts of gold discovered by various European explorers in the $15^{\text {th }}$ and $16^{\text {th }}$ Centuries AD along its coastline and hinterland [2] [3] [4]. The Ghanaian land mass has been settled by human beings for at least 30,000 years [2] [3] [4]. The currently-known survivors of the early human settlers of Ghana are called Guans (First Ghanaians) and their kingdoms and people are found in all 10 regions of Ghana. The Guans constitute about $4 \%$ of the country's population [1]. The other Ghanaians ( $96 \%$ of the population) started to arrive in the geographical area of Ghana from various parts of Africa from around $11^{\text {th }}$ Century AD onwards, spreading themselves throughout the country and formed states through wars and unions [2] [3] [4]. These other Ghanaians belong to eight ethnic groups and 55 subgroups. They are Akans (47.5\%; 20 subgroups), Mole-Dagbanis (16.6\%; 14 subgroups), Ewes (13.9\%), Ga/Ga Adangbes (7.4\%; three subgroups), Gurmas (5.7\%; eight subgroups), Grusis (2.5\%; five subgroups), Mandes (1.1\%; three subgroups); and All other groups (1.3\%) [1].

Ghana first emerged as a formal State-based geographical entity on 6 March 1844 when 17 traditional African states signed a treaty of friendship with the United Kingdom of Great Britain; the latter had then become the most powerful European nation-state power in that area of West Africa. These 17 traditional states were Abora, Agona (Agona Nsaba), Ajumako, Anomabu, Asikuma (Breman Asikuma), Assin Attandasu, Assin Apemanim, Cape Coast, Denkyira, Dixcove, Dominase, Ekumfi, Gomoa, James Town (Accra), Twifo, Wassa Amenfi and Wassa Fiase [2] [3] [4]. All 17 traditional states are in the Central, Western and Greater Accra regions of Ghana, and have 29 constituencies out of the 275 constituencies and account for about $11.6 \%$ of the population of Ghana [1].

The Treaty of 1844, signed in the old colonial capital town of Cape Coast, was an agreement between the 17 traditional African states and the United Kingdom for joint security against invasion from other traditional African States and European nation-state powers around the Gold Coast area and its hinterland. By 1902, the United Kingdom had conquered the other African traditional states within the current territorial area of Ghana and incorporated all of them into the Gold Coast entity as one country together with the original 17 traditional states which signed the Treaty of 1844 [3] [4]. The 1884 Berlin Conference formalised the scramble for African territory by European nation-states and resolved conflicts between the United Kingdom and France related to their fierce territorial competition in West Africa [3] [4].

Ghana gained political independence from Great Britain on 6 March 1957 after the efforts of various indigenous leaders in the $19^{\text {th }}$ and $20^{\text {th }}$ Centuries. The 
early pioneering leaders included Mr. John Mensah Sarbah (also known as Kofi Mensah) from Cape Coast and his group, Aborigines Rights Protection Society (ARPS) which emerged during the last decade of the $19^{\text {th }}$ Century and fought for land tenure rights and limited political rights of the indigenous people. The ARPS was a highly competent and successful organisation which was able to convince the British Government to abandon its land grabbing legislation in the Gold Coast by appealing directly to the British legislature in London.

The key catalyst and driver in the fight for Ghana's political independence was Dr. Kwame Nkrumah and his party, the Convention People's Party (CPP; founded in 1949) over the decade from 1947 to 1957, first as a member of the United Gold Coast Convention (UGCC) from 1947 to 1949, and later his work with the CPP from 1949 to 1957. The UGCC was founded in 1947 by Mr. George Alfred Grant (also known as Paa Grant), a wealthy Nzema timber merchant based in Takoradi, Ghana's third largest city. Mr. Grant brought together a group of intellectuals to discuss political issues of the Gold Coast at the time, paid their salaries and those of their aides and assistants, and financed the operating costs of the organisation. He also directly paid the travelling expenses and other costs to bring Dr. Nkrumah who was then in London to join the group as the Secretary-General in 1947.

Over the two-year period from 1947 to 1949, the UGCC was seen as largely an elitist ineffectual group with little connection to the masses of the people. The driving impetus for Ghana's independence started in 1949 with the formation of the centre-left mass-based movement, CPP by Dr. Kwame Nkrumah who broke away from UGCC. Ghana achieved independence on 6 March 1957, after three elections in 1951, 1954 and 1956, which were overwhelmingly won by the CPP. Thus, the 113-year journey of the development of the national entity called Ghana, which started in Cape Coast, the old capital of Ghana, with a proclamation of a treaty on 6 March 1844 by 17 traditional African States with the United Kingdom, ended exactly 113 years later on 6 March 1957 in Accra, the new capital, with the independence proclamation announced by Dr. Nkrumah, who was also a traditional leader from Wassa Fiase (Nsuaem), one of the 17 states which signed the Bond of 1844 .

After nine years of relatively stable government and moderate economic growth and sustained nation building involving extensive physical infrastructure, the country experienced the first of its five military coups on 24 February 1966. Ghana was then plunged into considerable political instability from 1966 to 1983 due to a series of successful military coups and a number of attempted but unsuccessful coups. The 60-year history of the modern nation state of Ghana, from 1957 to 2017, could be classified into three main periods as follows: (a) the nine-year post-independence period from 6 March 1957 to 24 February 1966 of Dr. Nkrumah and the CPP, (b) the 27 -year period of political and economic instability from 24 February 1966 to 6 January 1993 [5]. The third period is from 7 January 1993 to the present date and is the current Fourth Republican era. 
The Fourth Republican era (1993 to 2017) has been marked by relative political and economic stability and several other characteristics. These include continuous structural adjustment programmes initiated by the Government of Ghana with the support of the International Monetary Fund and the World Bank, and Western donor funds being a major source of government budget funding from 1993 to 2011, especially during the period from 2001 to 2008 [6]. Ghana officially became a lower-middle-income country in 2010 after its per capita income rose over 1000 United States dollars (US\$) based on economic growth driven by relatively large amounts of donor funds from Western countries, and cancellation of two-thirds of its US\$6.3 billion foreign debts in December 2006 (US\$4.2 billion).

Despite the relative political and economic stability over the last 24 years, the country has been grappling with a number of socio-economic problems over this period. One is the lack of eligibility for most concessional international loans and grants with the country attaining an official lower-middle-income status in 2010 meaning that Ghana it had to rely on commercial bonds and money markets to borrow money for development. Other challenges include excessive government spending especially in years of national elections [7] [8]. Another problem that has strongly emerged during the Fourth Republic era from January 1993 to the present time is the constantly politically-polarised environment linked to the consistent mobilisation of ethnicity and regional differences for political power by the two main political parties, the currently ruling New Patriotic Party and the main opposition party, the National Democratic Congress [6] [7]. This ethnicity mobilisation for political power was also present during the political instability era of the country from 1966 to 1983 when successful military coups in the country were largely organised by military elites from a few dominant ethnic subgroups; the issue has resurfaced in a different form during civilian multi-party governance in the Fourth Republic.

\section{Problem Statement and Impacts of Natural Hazards in Ghana}

Ghana, like many other countries, is prone to a range of environmental and natural hazards such as droughts, earthquakes, floods, severe rains and wind storms. The recurrence of natural hazards, including weather-related hazards, such as droughts and floods, has been a marked feature of Ghana's 60-year post-independence period; however many natural hazards have been reported in Ghana much earlier before independence. Major earthquakes occurred in Ghana in 1615, 1636, 1862 and 1939 resulting in several deaths and widespread destruction of property including the complete destruction of Axim Town in 1636 [9]. The regular occurrences of droughts and floods have had major impacts on the standards of living of people in the country. A major source of political and economic instability since independence has been the effects of natural and environmental disasters such as severe droughts and their management by societal authorities; major natural disasters linked to the El Nino weather phenomenon 
occurred in Ghana in 1962/63, 1976/77, 1982/83, 1998/99, 2006/2007 and 20132015 period leading to higher inflation and hardships on the population.

These natural hazards tended to precede the change in government a couple of years later through military coups or competitive national elections apparently due to the stress imposed on the people and the overall management of these hazards by the incumbent government. Thus, for example, the 1978 palace coup that overthrew the military government of General Kutu Acheampong was linked to the hardships imposed on the general population by the severe El-Nino-linked droughts in 1976 and 1977. Further, during the Fourth Republican era in Ghana since January 1993, the change in government through national elections in December 2000 and December 2008 were preceded by the occurrence of a moderately severe El Nino weather phenomenon during the previous two years [9]. More recently, the change in government during the December 2016 national election was heavily influenced by the electricity and power shortages linked to the severe El Nino weather phenomenon that occurred in the country from 2013 to 2015.

Environmental and natural hazards are known to affect the outputs and productivity of agriculture and related industries; construction industry and water and utilities industries. They impact the services sector through cutting and destruction of service lines. These hazards are also known to have severe macroeconomic impacts including reduction in economic growth, increase in inflation and depreciation of the local currency due to reduced levels of agricultural commodity exports. For example, during the 1977 and 1983 severe droughts linked to the El Nino weather phenomenon, annual inflation in Ghana was above $100 \%$ in both years and were historically the highest ever recorded in the country [8]. These very high inflation levels in those two years were directly linked to sharply reduced outputs in the agricultural sector due to lack of rains. In more recent years, moderate droughts such as those that occurred in 1998/99, $2006 / 2007$ and 2013 to 2015 , resulted in very low water levels in the hydro-based dams, the major source of electricity energy for Ghana [10].

The scale of the impacts of natural and environmental hazards is influenced by the three main factors: (a) the severity and strength of the hazard, (b) the vulnerability of the population at risk, and (c) the general and specific preparedness of the population at risk. The severity of the hazard is normally difficult to control by human beings with current levels of technology. Nevertheless, it is possible for a society to reduce the level of impacts of the hazard through reducing the vulnerability of the population at risk and strengthening the preparedness of the population to deal more effectively with the hazard once it occurs. The extent of societal costs to the population of Ghana is exhibited annually during the May to July period as a result of the constant flooding in Accra, the capital city and in many other parts of the country. An environmental policy of the government of Ghana is to use its agencies to help the population prepare adequately to deal with the impacts of these hazards. This policy is articulated in various official documents such as the Poverty Reduction Strategy, 2003-2006, 
the Growth and Poverty Reduction Strategy, 2006-2009 and the Ghana Shared Growth and Development Agenda, 2010-2013) [11] [12].

The effects of natural disasters, though often local, can assume international concerns and media attention. Natural hazards such as volcanic eruptions tend to have regional impact and receive considerable mass media attention. In Ghana the National Disaster Management Organization (NADMO) is a major body with the sole responsibility to manage natural disasters and emergencies in the country. NADMO was established by ACT 517 of 1996 under the Ministry of Interior with representatives drawn from other ministries. NADMO succeeded the National Mobilisation Programme (NMP) which was established after the 1982-1983 crises of droughts, bushfires, and deportation of about 1.2 million Ghanaians from Nigeria in 1983. NADMO's mandate includes the drawing of plans to prevent disasters or mitigate their effects on residents in Ghana, to coordinate activities before and during emergencies as well as ensuring post disaster rehabilitation, reconstruction and resettlement [11] [12]. The expulsion of 1.2 million Ghanaians from Nigeria in 1982/1983 was in direct retaliatory response to the Aliens Compliance Order of November 1969 enacted by the Progress Party government of Dr. Kofi Abrefa Busia during the Second Republic (October 1969 to January 1972) which forced the removal of over one million West Africans from Ghana, many of whom had stayed in the country for several decades [13].

Another important element in societal preparedness against environmental and natural hazards is the production and use of improved weather information and meteorological products to provide advance warning and properly manage these hazards. In Ghana, the public agency responsible for producing meteorological services is the Ghana Meteorological Agency (GMet). GMet, like many public agencies in Ghana, is facing financial challenges due to reduced real level of spending and government resources allocated for its programmes and projects. Public meteorological services, like most government services in Ghana, have also been marginalised by the increasing levels of privatization of government services since April 1983 with the advent of SAPs in Ghana implemented by the Government of Ghana with the assistance of international lending agencies such as the World Bank and the International Monetary Fund. Several decades of implementing various forms of SAPs have contributed to the weakening of the infrastructure and technical manpower of the Agency. The evidence of underfunding of GMet is apparent from the closure of many manned weather stations in Ghana over the last 30 years and loss of many highly-skilled personnel.

In our view, a major reason for the marginalisation of GMet is the inadequate assessment of the economic value and social benefits of the services that it produces for the Ghanaian society. Enhanced resourcing of GMet is necessary to help advance broad-based inclusive economic growth given that its services are used by virtually all the sectors of the economy of Ghana as inputs in their production processes, and by many householders as consumption goods for their 
day-to-day living. The services of GMet are also critical in saving lives and properties. The assurance of appropriate and adequate level of funding for GMet in order for the Agency to effectively carry out its responsibilities requires clear demonstration to policy makers and the general public of the economic value and social benefits of meteorological services [9].

The means of communicating meteorological information and products to the Ghanaian people have been enhanced by the increasing penetration and access of mobile phones and Internet use in Ghana. Mobile phone service penetration in Ghana has now reached $100 \%$ of the population with the information and communication industry being one of the fastest growth industries in Ghana over the last decade as documented by the Ghana Statistical Service [14]. The six mobile telephone companies in Ghana have been producing several varieties of information products for the general public such as religious messages, tourism information and guides, music and entertainment products and political party information and campaigning schedules. An area that could benefit from the increased telephone access of the population is the provision of weather warnings and information from GMet to the general public through extensive use of mobile phones. This has the potential of saving considerable costs as the public can be better informed to deal with natural hazards.

The main objective of this survey-based study was to evaluate the public weather services produced by GMet from the perspective of users of these services in the formal services sector of the economy in Accra, Ghana and establish the economic value that these users attached to the services using the contingent valuation method. The rest of this paper is organised as follows: the next section provides an overview of the literature of natural hazards and the provision of meteorological services. This is followed by a discussion of the methodology used in the study. The results of the survey are provided next. The conclusions of the study, the related recommendations, and the list of cited references follow as the final part of this paper.

\section{Literature Review}

\subsection{Natural Hazards and Their Management}

Natural hazards are differentiated from normally-occurring day-to-day threats of life by their relative rarity and the threats that they impose through possible loss of human lives, damage to infrastructure and services and high levels of societal cost that substantially exceeds normal expectations [9]. Three types of natural hazards are identified by Chapman [15]. These are those coming mainly from the atmosphere and hydrosphere such as thunderstorms and droughts, those that originate from the lithosphere such as earthquakes, volcanic explosions and dust storms and hazards that originate from the biosphere such as viruses and bacteria [15]. The vulnerability of societies is dependent to the socioeconomic conditions of the population and is ultimately linked to socio-economic indicators such as population dynamics, development patterns, social characteristics and macro-economic conditions prevailing in the country [16]. 
Some scholars suggest that countries with relatively high proportion of the population being educated, have working natural disaster institutions, high foreign exchange reserves and good governance is in operation generally have a higher tendency to overcome the shocks of natural disasters and contain more quickly the side effects and induced effects of natural disasters after they have occurred [17]. Some authors also indicate that natural disasters tend to affect the lives of people in economically-developing countries more than those in economically-developed countries [18]. Benson and Clay [19] explain that the nature of loss and damages to developing countries from natural disasters depends on how strong the link is between the primary extractive sector and other sectors of the economy. They argue that strong links between the primary extractive sector and other sectors largely minimises the impacts of natural disasters. However, a weak link leads to natural disasters primarily affecting the primary extractive sector. Sikdmore and Hoya [20] argue that the impact of weather-related disasters may affect all countries differently; however weather-related disasters correlate positively with economic growth and productivity.

McEntire and Mathis suggest that economically-developed countries tend to experience less casualties and losses from disasters because they are equipped with better resources in terms of finance and technology to prepare adequately for natural disasters and also mitigate the damages posed by natural disasters [21]. Vogel and O'Brien [22] indicate that Africa is vulnerable to the vagaries of the weather and propose the collection and dissemination of accurate weather and climate information to reduce the loss and damages to individuals and communities as a result of natural disasters. The quality of the disseminated weather information to the public is affected by individual characteristics; as well social characteristics and political economy issues related to political governance, gender, ethnicity and wealth distribution also affect one's access and use of meteorological information [22].

\subsection{Meteorological Services as Tools to Deal with Natural Hazards}

It is clear from the basic introduction to natural hazards that meteorological agencies are important for the production of information concerning natural hazards originating from the atmosphere and hydrosphere for distribution to human beings to improve their economic welfare based on the classification of Chapman [15]. Information on the weather in each country of the world is produced by their respective National Meteorological and Hydrological Services (NMHS). The main responsibility of the NMHS is to collect, interpret and distribute weather information and products for the consumption of the general public as well as for specific economic sectors such as agriculture, construction, energy, insurance and health. The services provided by the NMHSs to the public may either be basic or tailored to meet the requirements of a specific sector. NMHS though are independent, they tend to work coordinate their activities with other NMHS within the regions they operate who in turn share information with the World Meteorological Organisation. 
The designated NHMS for the Republic of Ghana is the Ghana Meteorological Agency (GMet). GMet produces several types of products and services which can be categorised into appropriate groups based on the extent of cost-recovery of these products and services. These are categorised into the following groups: (a) public weather services and climate data production and archival: these are essentially public goods for which they are largely indivisible in nature and are available to the general public for safety and humanitarian considerations; (b) incremental cost-recovery services such as climate data and information products available to researchers at universities and other institutes. Users of these services are charged for the marginal or incremental costs of producing these data. These services include those related to aviation such as hourly meteorological reports, terminal aerodrome forecasts, significant weather reports; (c) Commercial or special services for which GMET attempts to charge fully for their costs of production. These include supply of climate data such as historical rainfall data to commercial companies such as Bloomberg and Wienco companies.

Meteorological agencies largely produce services which in one way or other deal with the supply of information and related products. Meteorological information could be defined as raw data been observed about the atmosphere and hydrosphere that have been processed and refined into forms useful to some human beings following the terminology of Davis and Olson (1985) [23]. In that sense, meteorological information also involves its transmission from its production source to the recipient source through signals; the quality of the signals could be affected by technical problems and/or issues related to understanding of the signals by the recipients which would establish the usefulness and economic value of the information in the sense of whether the information is useful to improve decision making. The quality attributes of meteorological information decide its total economic value. Quality attributes of information include relevance, aggregation, accuracy, convenience and timeliness [24] [25].

\section{Methodology}

\subsection{Description of the Valuation Methods Used to Value Meteorological Services}

Public weather services produced by GMet are largely public goods in nature due to their two distinct properties: indivisibility and non-excludability in consumption by individuals. Indivisibility implies that the good once available can be consumed by everybody in that particular market without its quality or quantity being affected. The non-excludability property implies that the good is available for all to use and no one is excluded from consuming that good. Public weather services by nature fulfil these two properties of public goods as they are freely available through free-to-use and widely-accessible platforms such as radio and television and their use does not reduce the quality or the quantity of the services that are supplied. Public weather services in Ghana, the subject of our study, are classified as public goods (non-market goods and services) requiring a variety of techniques for their valuation. 
There are four main methods developed in the literature in resource and environmental economics to value non-market goods and services such as public weather services [26]-[31]. Briefly, these are as follows: (a) the use of market prices, (b) expenditures incurred to consume method a good popularised by the travel cost method, (c) hedonic pricing method and (d) contingent valuation method. The use of market prices to value goods and services is the appropriate method where there is an established competitive market for the product and the market prices reflect the collective value established by many producers and many consumers existing in that market. As indicated earlier, there are special types of commercially-produced meteorological services which fall into the category of purely private meteorological services for which users are charged for the full cost of provision.

The travel cost method originally proposed by Hotelling in 1949 [32], and first actualised in research work by Clawson in 1959 [33], is a revealed preference method that is used to establish the economic value of recreational sites based on the amounts of money and other resources that individuals incur to visit these sites. The travel cost method can be generalised as part of the type of valuation called the costs or expenditures incurred to consume or use a good. With this generalisation, the general expenditures incurred to consume or use a good method, popularized by the travel cost method, is a technique that can be used to estimate the economic benefits of non-market goods, assets and resources that are used by human beings through various means.

These include (1) visits to community forests to fetch firewood, (2) visits to hometowns for festivals and funerals, (3) visits to community parks for personal and family relaxation, (4) visits to traditional African religious shrines for consultations with regards to medical and life problems, and (5) the value of romance-based friendship proxied by partner-search costs incurred by potentially-marriageable males and females in various dating markets involving visitation costs and exchange of material and non-material gifts. For meteorological services, Anaman and Lellyett (1996) used this expenditures incurred to consume a good method to estimate the minimum economic value of public weather services in Sydney, Australia [34]. This involved valuing search and related costs incurred by the public to acquire and receive public weather service information dealing with public weather forecasts and warnings. They established a value of 2.868 million Australian dollars for the 1994/95 financial year [34].

The hedonic pricing method is another revealed preference method used to value non-market goods and services such as meteorological services. The basic premise of the hedonic pricing method is that the non-market good has attributes or special features that when used lead to an increase in the consumption and/or production of closely-related market goods and services. For meteorological services, in the case of terminal aerodrome forecasts (TAF), highly-accurate forecasts of landing conditions around aerodromes or airports allow some airlines to save fuel by not carrying the discretionary alternate fuel for another airport (the so-called ALT FUEL) thus saving some costs. Several studies have been 
undertaken in Australia which established the minimum economic value for TAFs through the fuel savings for Qantas Airways Corporation [35] [36] [37]. Other studies have used the hedonic pricing method to derive economic values for various meteorological services [38] [39] [40].

The fourth method for valuing non-market meteorological services is the contingent valuation method which is a stated preference method. Briefly, the CVM creates an artificial hypothetical market and through a random-based scientific survey which requests respondents to state the maximum amount of money that they are willing to pay for a particular rather than be without that good or the minimum amount of compensation that they would like to receive for a reduced quality of a resource. CVM studies have been conducted widely around the world and for meteorological services, there have been several studies conducted for valuation of various public weather services [31] [34] [40]-[45]. The strengths and weaknesses of the CVM are discussed extensively by Asafu-Adjaye [30]. The limitations of CVM are addressed in the practical application to value the public weather services produced by GMet outlined in this study. The next section of this report deals with the application of CVM for our study.

\subsection{Application of Contingent Valuation Method for This Study}

The simulation of the economic valuation of a good, through the creation of the artificial market for public weather services, implies a choice between two situations: (a) with the use of public weather services $\left(Q_{1}\right)$ or $(b)$ without the use of public weather services $\left(\mathrm{Q}_{0}\right)$ given the current existing income level of the respondent at the time of the study. A change from $\mathrm{Q}_{0}$ to $\mathrm{Q}_{1}$ implies an economic sacrifice (in giving up the consumption of some material goods and services) from the current level of income $\left(\mathrm{Y}_{0}\right)$ by a certain amount that would establish the same level of utility with the use of public weather services as the same level of utility without the use of public weather services. This sacrifice of income which the respondent is requested to indicate, given his/her current existing income, represents the willingness-to-pay (WTP) for the public weather services. It can also be implied that the WTP would increase with increasing quality of the public weather services, say moving from $Q_{1}$ to $Q_{2}$, and $Q_{2}$ to $Q_{3}$ as shown in Figure 1 with the curve $\mathrm{U}_{0} \mathrm{U}_{0}$ representing the constant utility (satisfaction) curve. Note that $\left(\mathrm{Y}_{0}\right.$ minus $\left.\mathrm{Y}_{1}\right)$ represents the WTP for basic public weather services of quality $\mathrm{Q}_{1}$; and $\left(\mathrm{Y}_{0}\right.$ minus $\left.\mathrm{Y}_{2}\right)$ representing WTP for public weather services of quality $\mathrm{Q}_{2}$ (or improved level 1); and $\left(\mathrm{Y}_{0}\right.$ minus $\mathrm{Y}_{3}$ ) representing WTP for public weather services of quality $\mathrm{Q}_{3}$ (or improved level 2).

In the application of the CVM to our study, we used the iterative bargaining method to derive the economic value of the public weather services from the randomly selected survey respondents. The iterative bidding method is much more in line with Ghanaian market conditions where bargaining is a normal and consistent feature between buyers and sellers. Respondents were initially requested to indicate their maximum WTP to use the public weather services produced by GMet or be without these services given their current incomes. This 


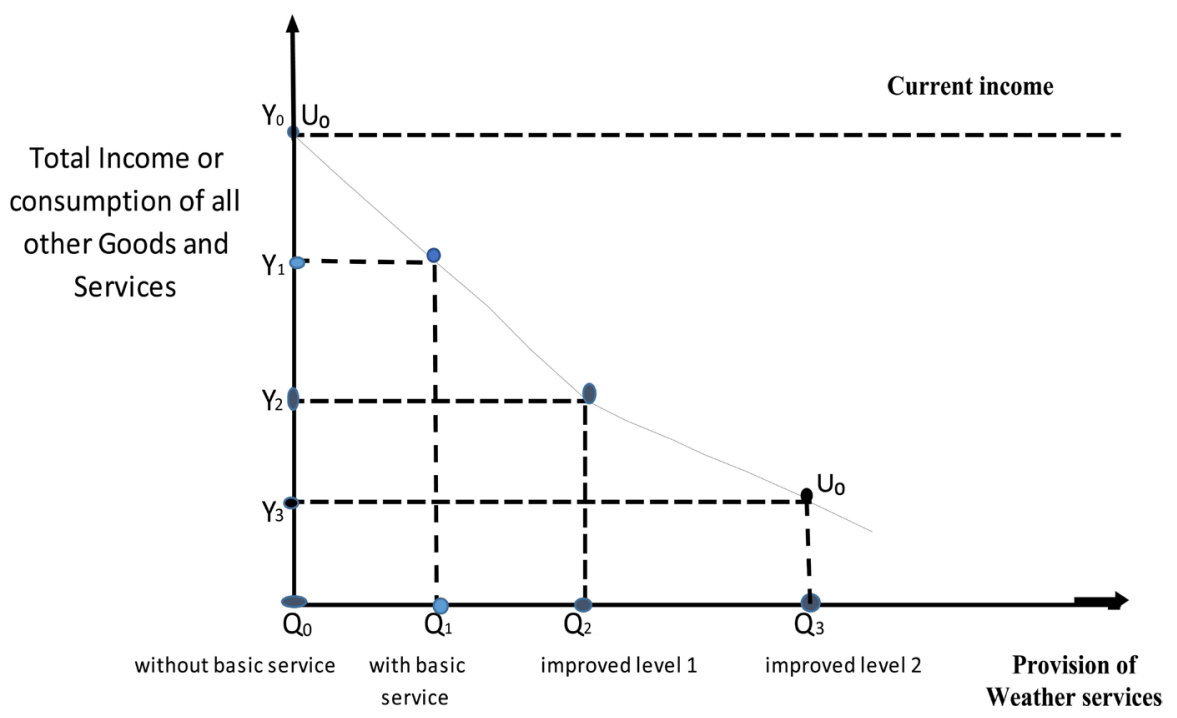

Figure 1. An illustration of the contingent valuation method to determine the economic value of both basic public weather services and improved public weather services based on the concept of constant utility or satisfaction curve and current income of the person.

was considered a starting bid. The starting bid was increased by one Ghana cedi at a time until the interviewer and the respondent mutually agreed on the final price. The final price was taken to be the maximum WTP or the economic value attached to the use of public weather services produced by GMet rather than be without these services.

\subsection{Survey Procedures and Administration}

The real economy of Ghana is classified into three sectors: agriculture, industrial and services [14]. Ghana's current real economy is clearly dominated by the services sector which accounted for $56.9 \%$ of GDP in 2016. The services sector contributed on average of $50.8 \%$ of GDP of Ghana compared to the contributions of $25.8 \%$ and $23.4 \%$ for agriculture and industrial sectors over the 2006 to 2016 using the rebased figures of the Ghana Statistical Service compiled in 2010 [14]. Further, the services sector was the largest employer of all the three economic sectors employing $42.8 \%$ of the total employed population of Ghana of $10,243,476$ compared to proportions of $42.0 \%$ for agriculture and $15.2 \%$ for the industrial sector based on the 2010 Population Census (Ghana Statistical Service, 2013, p. 265) [1]. The services sector in Ghana comprise of nine sub-sectors as follows: (a) trade, repair of vehicles and households, (b) hotels and restaurants, (c) transport and storage, (d) information and communication, (e) finance and insurance activities, (f) real estate, professional and support service activities, (g) public administration and defence, (h) education, (i) health and social work and (j) community, social and personal service activities [14].

The focus of our study is on the services sector for which little research work has been undertaken with regards to the use of meteorological services by workers and managers in Ghana. Accra was chosen for our initial study on the use of meteorological services because it accounts for about one-sixth of the population 
of Ghana [1] [47], produces about one-third of the country's GDP, and hosts firms in all the nine subsectors of the services sector. The survey was undertaken in Accra over a period of six months from March to September 2016. A pilot survey involving 10 respondents was undertaken in Accra in January 2016. A list of past, current and potential users of public weather services in the services sector was provided by GMet. This list was used to undertake a random survey of users of public weather services living in Accra who were in the formal services sector based on initial contacts at their work places and/or homes via adherence to the normal protocol and regulations. The formal sector deals with firms and individuals properly registered and documented by relevant governmental authorities and hence are more likely to have their workers paying income taxes which are essentially used to run and operate the machinery of the government and State institutions such as GMet. In this study, our specialised focus was on the formal services sector rather than the entire services sector.

A total of 150 respondents were randomly chosen from the various institutions by initially contacting the respective Heads of institutions and firms in the formal services sector for actual and potential users of meteorological services based on the list supplied by GMet. We chose a minimum of one person and a maximum of $1 \%$ of the actual and potential users provided by the institutions and agencies randomly. These respondents were contacted based on both the use of self-administered questionnaires and/or through personal or face-face interviews using a questionnaire. Several respondents provided information based on the self-administered questionnaires with the completed questionnaires picked from their offices or from their homes after they had completed them. The questionnaires were personally delivered to them. The choice of optimal sample size is based on the work of de Vaus [48]. Using the method of de Vaus, we derived the minimum optimal sample size of 120 based on the expected population of workers in the formal services sector Accra (refer to Table 3 which defines Accra, the area of our study to include Accra Metropolitan Area, Adenta and Ledzokuku-Krowor districts to capture the urban compactness of the three areas). The minimum sample size was increased by 30 to reach 150 , an oversampling of 30 or $25 \%$. In all, 102 out of the 150 respondents completed the questionnaire within the six-month study period, a response rate of $68.0 \%$.

\subsection{Analysis of Survey Data}

Data collected from the field was entered in to the Microsoft Excel Software Programme for onward analysis. Simple descriptive statistical techniques were employed where appropriate. Respondents' assessment of quality attributes of weather information were statistically analysed. The WTP for weather services was analysed by use using econometric analysis. The WTP function for the basic public weather services is described below in Equation (1).

WTP BASIC PUBLIC WEATHER SERVICES

$=\mathrm{A}_{0}+\mathrm{A}_{1} \mathrm{SEX}+\mathrm{A}_{2}$ STUDENT $+\mathrm{A}_{3}$ USE RATE

$$
+\mathrm{A}_{4} \text { BUSINESS OR WORK USE }+\mathrm{A}_{5} \text { OVERALL USEFULNESS }+\mathrm{U}
$$


where WTP BASIC PUBLIC WEATHER SERVICES was the maximum amount of money that the user was willing to pay for the basic public weather services rather than be without them;

SEX was a dummy variable with 1 representing males and zero for females;

STUDENT was a dummy variable with 1 for students and zero for non-students;

USE RATE was the number of times that the respondent used the public services;

BUSINESS OR WORK USE was a dummy variable with 1 representing respondents who used the basic public weather services for business or work and zero for those who used the services as consumption goods only;

OVERALL USEFULNESS was a Likert-type continuous variable for the overall quality of the basic public weather services as perceived by the respondent; and

$U$ was the equation error term assumed to have zero mean and constant variance.

\section{Results}

\subsection{Summary Socio-Economic Characteristics of Respondents}

The socio-economic characteristics of the survey respondents are summarised in Table 2. Slightly over one-third (36.3\%) of the 102 respondents were female indicating that male respondents form the majority group by sex. In terms of occupation and profession, the single biggest group of respondents worked for

Table 1. Proportions and numbers of workers employed in the formal sector, formal services sector of the economy for Ghana and Accra based on 2010 National Census.

\begin{tabular}{|c|c|c|c|}
\hline Type of Worker & $\begin{array}{c}\text { National } \\
\text { (Whole } \\
\text { of Ghana) }\end{array}$ & $\begin{array}{c}\text { Greater } \\
\text { Accra } \\
\text { Region }\end{array}$ & Accra \\
\hline Number of All Employed Workers & $10,243,447$ & $1,801,279$ & 993,506 \\
\hline Number of Workers in the Formal Sector & $1,413,596$ & 484,544 & 276,207 \\
\hline Number of Workers in the Services Sector & $4,384,195$ & $1,316,735$ & 773,510 \\
\hline Number of Workers in the Formal Services Sector & 605,019 & 354,202 & 214,836 \\
\hline Proportion of the Number of All Employed Workers (Percent) & 100.0 & 100.0 & 100.0 \\
\hline $\begin{array}{l}\text { Proportion of All Workers Accounted by Number of Workers } \\
\text { in the Formal Sector (Percent) }\end{array}$ & 16.8 & 26.9 & 27.8 \\
\hline $\begin{array}{l}\text { Proportion of All Workers Accounted by Number of Workers } \\
\text { in the Services Sector (Percent) }\end{array}$ & 42.8 & 73.1 & 69.0 \\
\hline $\begin{array}{l}\text { Proportion of All Workers Accounted by Number of Workers } \\
\text { in the Formal Services Sector (Percent) }\end{array}$ & 5.9 & 19.7 & 21.6 \\
\hline
\end{tabular}

Source: Computed from data available from the Ghana Statistical Service 2010 National Population Census National Analytic Report and the 2010 National Population Census Regional Analytic Report for Greater Accra Region. Notes: Accra includes Accra Metropolitan Area, Adenta and Ledzokuku-Krowor. The number of workers in the formal services sector in Accra was 214,836 in 2010 (refer to Table 1). Assuming a growth rate of $2.5 \%$ per year consistent with the national average, the number of formal services sector workers in Accra was estimated to be 249,144 . The latter figure was then used as the population size for which a random sample size was selected using the sampling from an infinite population procedure given the large size. 
Table 2. Percentage of the 102 survey participants based on their summary of socioeconomic characteristics.

\begin{tabular}{|c|c|}
\hline Item/group & Percentage (\%) \\
\hline \multicolumn{2}{|l|}{ Sex } \\
\hline$>$ Female & 36.3 \\
\hline$>$ Male & 63.7 \\
\hline \multicolumn{2}{|l|}{ Occupation and profession } \\
\hline$>$ Student & 12.1 \\
\hline$>$ Individual firm or entity & 17.2 \\
\hline$>$ Private corporation & 21.2 \\
\hline$>$ Public corporation & 10.1 \\
\hline$>$ Government department or civil service & 14.1 \\
\hline$>$ Educational institution & 16.2 \\
\hline$>$ Research institution & 9.1 \\
\hline \multicolumn{2}{|c|}{$\begin{array}{l}\text { Individual works for agency which distributes public weather information } \\
\text { to the general public such as radio and television }\end{array}$} \\
\hline$>$ Distributor of weather information & 4.9 \\
\hline$>$ Non-distributor of weather information & 95.1 \\
\hline \multicolumn{2}{|c|}{ Use of public weather services for work or business } \\
\hline$>$ Users & 39.2 \\
\hline$>$ Non-users & 60.8 \\
\hline \multicolumn{2}{|c|}{$\begin{array}{l}\text { Intensity of use of public weather services as either consumption good } \\
\text { and/or for business and work uses }\end{array}$} \\
\hline$>$ Never use public weather services & 1.5 \\
\hline$>$ Once a month or less & 6.1 \\
\hline$>$ Once a fortnight & 3.0 \\
\hline$>$ Once a week & 3.0 \\
\hline$>$ Several times a week & 9.1 \\
\hline$>$ Once a day & 40.9 \\
\hline$>$ Twice a day & 21.2 \\
\hline$>$ Thrice a day & 9.1 \\
\hline$>$ Four times a day & 1.5 \\
\hline$>$ More than four times a day & 4.5 \\
\hline \multicolumn{2}{|c|}{$\begin{array}{l}\text { Willingness to pay some money for public weather services based on the } \\
\text { current quality and characteristics of these services }\end{array}$} \\
\hline$>$ Yes & 87.7 \\
\hline$>$ No & 12.3 \\
\hline
\end{tabular}

private companies; this was followed by those working for individual firms, and then those working in educational institutions. Only five out of the 102 respondents (4.9\%) worked for a distributor of weather information.

\subsection{Use and Valuation of Public Weather Services}

Almost four out of ten respondents (39.2\%) used the public weather services for work or business. Therefore just slightly over six out of 10 respondents used the weather services only as consumption goods that are for the convenience of carrying out their day-to-day living activities. About $56.8 \%$ of respondents used the 
public weather services for planning their daily activities. These daily activities include deciding on what type of clothes to wear, preparing to harvest rainfall for household consumption given the likelihood of rains, sun drying of food materials such as cassava, maize and pepper, and sun drying of washed household clothes outside the house. Protecting themselves and their household property against adverse weather conditions are some of the major uses of public weather services elicited from the survey. This personal protective use of public weather services was declared by about one-third of the respondents (33.3\%). Carrying an umbrella along while going to town because of the possibility of rainfall and closing windows in the house before leaving for work because of the possibility of rainfall are examples of such activities.

In terms of intensity of use of weather services either as a consumption good and/or for business and work uses, the most popular intensity of use was once a day $(40.9 \%)$ followed by twice a day (21.2\%). Only two of the respondents (1.5\%) indicated that they had never used the public weather services. The vast majority of the respondents (87.7\%) indicated their willingness to pay some money for the public weather services based on their current quality and characteristics of these services.

Table 3 provides users' quantitative assessment of the seven ideal attributes of information applicable to the public weather services produced by the Ghana Meteorological Agency. The highest-ranked attribute was relevance with an average score of 3.547 out of a maximum score of 5.0. Ease of understanding of the information contained in the public weather services was ranked the second most important with an average score of 3.444 followed by the overall usefulness of the services which had an average score of 3.422. In general, all the seven attributes had average scores of over 3.0; however the overall average scores fluctuated between moderate to high ranking and not very high or exceptional quality. The low coefficients of variation of the average scores reported in Table 3 represented the close to general consensus on the moderate quality of the services. Respondents made several suggestions for the improvement of the public weather services. A general consensus was that the public weather services need to be provided more frequently through the mass media. Rather than the current format whereby public weather services and information on weather are provided as part of the hourly evening news on the major television stations in the country, weather information need to be provided more regularly especially updates on the weather possibly hourly through the radio and television stations, especially the rapidly-growing mass media broadcasting in the 14 government-sponsored local Ghanaian languages namely Akuapem Twi, Asante Twi, Fante, Nzema, Dangme, Ga, Ewe, Dagaree, Dagbani, Gonja, Gurune, Kasem, Kusaal and Hausa.

Table 4 reports on the WTP economic values for both the basic public weather services and improved public weather services derived through the iterative-bidding process using the contingent valuation method. The average monthly WTP was 16.67 Ghana cedis per month. One United States dollar was 
Table 3. Users' quantitative assessment of seven ideal attributes of information inherent in the public weather services produced by the Ghana Meteorological Agency based on a survey of users working in the formal sector of the economy in Accra, Ghana.

\begin{tabular}{cccc}
\hline Attribute of ideal information & $\begin{array}{c}\text { Average score } \\
\text { of importance }\end{array}$ & $\begin{array}{c}\text { Standard deviation } \\
\text { of score }\end{array}$ & $\begin{array}{c}\text { Coefficient of } \\
\text { Variation }\end{array}$ \\
\hline Relevance & 3.547 & 0.795 & 0.224 \\
Timeliness & 3.381 & 0.792 & 0.234 \\
Frequency & 3.397 & 0.730 & 0.215 \\
Ease of understanding & 3.444 & 0.819 & 0.238 \\
Adequate level of details & 3.359 & 0.675 & 0.201 \\
Accuracy & 3.159 & 0.787 & 0.249 \\
Overall usefulness & 3.422 & 0.730 & 0.213 \\
\hline
\end{tabular}

Notes: The scoring is based on 5 denoting that the particular attribute of ideal information is present in the public weather services at a very high value, 4 represents a high value of the attribute, 3 moderate level of value of the attribute, 2 low level of value of the attribute and 1 very low level of value of the attribute in the public weather services. The coefficient of variation is the standard deviation divided by the mean score.

Table 4. Elicited average monthly economic values (WTP) expressed in Ghana cedis of public weather services produced by the Ghana Meteorological Agency based on a survey of users working in the formal services sector in Accra, Ghana using the contingent valuation method.

\begin{tabular}{|c|c|c|c|}
\hline Item & Mean & $\begin{array}{l}\text { Standard } \\
\text { Deviation }\end{array}$ & $\begin{array}{l}\text { Coefficient } \\
\text { of variation }\end{array}$ \\
\hline $\begin{array}{l}\text { WTP for basic public weather services using the open-ended } \\
\text { method of contingent valuation }\end{array}$ & 14.57 & 19.49 & 1.34 \\
\hline $\begin{array}{l}\text { WTP for basic public weather services using the iterative bidding } \\
\text { method of contingent valuation }\end{array}$ & 16.67 & 20.47 & 1.23 \\
\hline $\begin{array}{l}\text { Bias value in the use of the open-ended method of contingent } \\
\text { valuation to estimate the value for basic public weather services }\end{array}$ & 2.10 & 4.46 & 2.13 \\
\hline $\begin{array}{l}\text { WTP for improved public weather services using the open-ended } \\
\text { method of contingent valuation }\end{array}$ & 21.54 & 27.83 & 1.29 \\
\hline $\begin{array}{l}\text { WTP for improved public weather services using the iterative } \\
\text { bidding method of contingent valuation }\end{array}$ & 24.06 & 29.28 & 1.22 \\
\hline $\begin{array}{l}\text { Bias value in the use of the open-ended method of contingent } \\
\text { valuation to estimate the value for improved public weather services }\end{array}$ & 2.52 & 4.81 & 1.91 \\
\hline
\end{tabular}

Note: The coefficient of variation is the standard deviation divided by the mean score.

worth about 3.85 Ghana cedis at the time of the survey in 2016. Using the open-ended approach, the monthly average WTP was 14.57 Ghana cedis, representing an undervaluation of 2.10 Ghana cedis per month or about $12.6 \%$. This result confirmed the superiority of the iterative-bidding process over the open-ended technique to elicit WTP values. As suggested from Figure 1, the perceived improved quality of public weather services would be commensurate with higher economic values as expressed by average WTP elicited from respondents.

This suggestion was confirmed by the results provided in Table 4 . The aver- 
age monthly WTP increased by almost one-third from 16.67 Ghana cedis to 24.06 Ghana cedis. The size of the bias or undervaluation using the open-ended method was 2.52 Ghana cedis per month or $10.5 \%$. The coefficient of variation of the WTP values or the economic values was very high across all the different types of estimated values. The ability or willingness to pay for the basic and improved public weather services would likely depend on several socio-economic characteristics given the sheer nature and scale of the variability in the elicited economic values. Hence we conducted a multiple regression analysis of the factors that could influence the WTP values for both the basic public weather and improved public weather services. The results of the analysis are discussed in the next section.

\subsection{Multiple Regression Analysis of Factors Influencing the WTP of Basic and Improved Public Weather Services}

Table 5 provides a summary of the regression analysis of factors influencing the WTP (economic value) attached to the basic public weather services by users in the formal services sector in Accra, Ghana. The overall power of model is modestly strong as measured by $\mathrm{R}^{2}$ of $40.6 \%$ especially given the cross-sectional nature of the data used for the analysis. Given the relatively small size of the sample used for the analysis, it is important to check for normality of the regression error term as this would allow the established sample parameters to be generalised to the unknown population parameters. The Shapiro-Wilk test of normality confirms the normality of the error term as the null hypothesis of normality could not be rejected based on the available evidence from the data.

The statistically significant factors influencing the economic value of the basic public weather services are USE RATE, BUSINESS or WORK USE and OVERALL USEFULLNESS. These three variables are all directly related to the use of the services. Given the definition of USE RATE, people who intensively use the basic public weather services are prepared to pay more for the services rather than be without these services compared to those who use the services less intensively. Those respondents who use the services for either business or work activities have greater values attached to the public weather services and are prepared to pay for these services rather than be without them.

The overall usefulness of the basic public weather services essentially captures their quality and it is not surprising that based on the Likert scale measurement index of 1 to 5 , those who grade the services as of higher quality are prepared to pay more for the services. This is line with the generally accepted proposition that higher-quality services are more valuable than lower-quality services (refer to Figure 1). From Table 4, the two direct socio-economic variables, SEX and STUDENT are not statistically significant; however the signs of the parameters of both variables are consistent with a priori expectations. Further, with their Student $t$ values having absolute levels greater than 1.0, these variables have to be kept in the model to avoid misspecification bias.

Table 6 reports on the results of the regression analysis of factors influencing 
Table 5. Regression analysis of the economic value (WTP) of the basic public weather services produced by the Ghana Meteorological Agency based on a survey of users in the formal services sector in Accra, Ghana. Dependent variable is the amount of money in Ghana cedis that the user is prepared to pay on a monthly basis for access to public weather services rather than be without them (WTP BASIC PUBLIC WEATHER SERVICES). Values are elicited based on the contingent valuation method using the iterative (bargaining) method of elicitation. WTP BASIC PUBLIC WEATHER SERVICES $=\mathrm{A}_{0}+\mathrm{A}_{1} \mathrm{SEX}+$ $\mathrm{A}_{2}$ STUDENT $+\mathrm{A}_{3}$ USE RATE $+\mathrm{A}_{4}$ BUSINESS OR WORK USE + $\mathrm{A}_{5}$ OVERALL USEFULNESS.

\begin{tabular}{|c|c|c|c|c|c|}
\hline Explanatory Variable & $\begin{array}{c}\text { Regression } \\
\text { Coefficient } \\
\text { Estimate }\end{array}$ & $\begin{array}{c}\text { Standardised } \\
\text { Regression } \\
\text { Estimate }\end{array}$ & $\begin{array}{l}\text { Student } \\
\mathrm{t} \text { value }\end{array}$ & $\begin{array}{c}\text { Probability } \\
\text { level of } \\
\text { significance }\end{array}$ & $\begin{array}{c}\text { Variance } \\
\text { inflation } \\
\text { factor }\end{array}$ \\
\hline CONSTANT & -45.617 & 0.000 & -2.948 & $0.005^{\star * *}$ & 0.000 \\
\hline SEX & 8.101 & 0.196 & 1.672 & 0.101 & 1.107 \\
\hline STUDENT & -13.077 & -0.122 & -1.052 & 0.298 & 1.095 \\
\hline USE RATE & 4.508 & 0.374 & 3.147 & $0.003^{\star * *}$ & 1.143 \\
\hline BUSINESS OR WORK USE & 16.586 & 0.409 & 3.476 & $0.001^{\star * *}$ & 1.116 \\
\hline OVERALL USEFULNESS & 8.023 & 0.289 & 2.373 & $0.022^{\star *}$ & 1.201 \\
\hline $\mathrm{R}^{2}$ & & & & & $0.406^{* * *}$ \\
\hline Adjusted $\mathrm{R}^{2}$ & & & & & $0.344^{* * *}$ \\
\hline F value & & & & & $6.550^{* * *}$ \\
\hline
\end{tabular}

Probability level of significance of normality of the regression error term based on the Shapiro-Wilk test of normality

Notes: ${ }^{* *}$ denotes statistical significance at $1 \%$ level. ${ }^{* *}$ denotes statistical significance at $5 \%$ level.

Table 6. Regression analysis of the economic value of improved public weather services produced by the Ghana Meteorological Agency based on a survey of users in the formal services sector in Accra, Ghana. Dependent variable is the amount of money in Ghana cedis that the user is prepared to pay on a monthly basis for access to improved public weather services rather than be without them (WTP IMPROVED PUBLIC WEATHER SERVICES). Values are elicited based on the contingent valuation method using the iterative (bargaining) method of elicitation. WTP IMPROVED PUBLIC WEATHER SERVICES $=\mathrm{B}_{0}+$ $\mathrm{B}_{1}$ SEX $+\mathrm{B}_{2}$ STUDENT $+\mathrm{B}_{3}$ USE RATE $+\mathrm{B}_{4}$ BUSINESS OR WORK USE + $\mathrm{B}_{5}$ OVERALL USEFULNESS.

\begin{tabular}{cccccc}
\hline \multirow{2}{*}{ Explanatory Variable } & $\begin{array}{c}\text { Regression } \\
\text { Coefficient } \\
\text { Estimate }\end{array}$ & $\begin{array}{c}\text { Standardised } \\
\text { Regression } \\
\text { Estimate }\end{array}$ & $\begin{array}{c}\text { Student } \\
\mathrm{t} \text { value }\end{array}$ & $\begin{array}{c}\text { Probability level } \\
\text { of significance }\end{array}$ & $\begin{array}{c}\text { Variance } \\
\text { inflation } \\
\text { factor }\end{array}$ \\
\hline CONSTANT & -53.551 & 0.000 & -2.333 & $0.024^{* *}$ & 0.000 \\
SEX & 9.695 & 0.171 & 1.387 & 0.172 & 1.137 \\
STUDENT & -14.490 & -0.101 & -0.834 & 0.409 & 1.097 \\
USE RATE & 5.515 & 0.340 & 2.744 & $0.009^{* * *}$ & 1.151 \\
BUSINESS OR WORK USE & 24.566 & 0.441 & 3.556 & $0.001^{\star * *}$ & 1.157 \\
OVERALL USEFULNESS & 9.401 & 0.234 & 1.845 & 0.072 & 1.212 \\
$\mathrm{R}^{2}$ & & & & & $0.387^{* * *}$ \\
Adjusted R & & & & & $0.321^{* * *}$ \\
F value & & & & & $5.814^{* * *}$
\end{tabular}

Probability level of significance of normality of the regression error term based on the Shapiro-Wilk test of normality.

Notes. ${ }^{* *}$ denotes statistical significance at $1 \%$ level. ${ }^{* *}$ denotes statistical significance at $5 \%$ level. 
the WTP (economic value) attached to improved public weather services. The nature of the improved public weather services is specified by the particular user. Similar to the results in Table 5, the use of the public weather services for business or work activities and the intensity of their use positively influenced their levels of economic value as measured by WTP values. However, the overall usefulness variable was not statistically significant at the $5 \%$ level though it was significant at the $10 \%$ level. The difference could be attributed to the variable measuring the perceived usefulness of the existing basic public weather services rather than the proposed improved public weather services which have not yet been produced.

\section{Conclusions and Policy Implications}

This paper is a report on a completed survey-based study dealing with users of public weather services (including weather warnings) in the formal services sector of the economy of Ghana and for those users based in Accra, the capital city of Ghana which accounts for one-sixth of the country's population and one-third of its GDP. This study is one of the few undertaken on the services sector of the economy in Ghana and employed a randomly-sampling survey technique to request information on the use of services and information produced by the GMET, the country's official producer and archival of meteorological data, information, products and services. The results of the analysis of survey data indicated that virtually all the respondents used public weather services produced by GMET. The users generally considered the quality of the public weather services to be moderate based on their specific ranking of the seven ideal attributes of information-relevance, timeliness, frequency, ease of understanding, adequate levels of details, accuracy and overall usefulness.

Using the contingent valuation method to ascertain the economic value of public weather services, the respondents were clearly able to indicate their economic values and considered them to be valuable goods with $87.7 \%$ of them prepared to pay for the public weather services rather than be without them. This proportion is much higher than in similar studies reported elsewhere in the world [31] [34] [46]. A reason for this difference could be that our current study was focused on the formal services sector which would likely be made up of middle-income class workers and relatively more educated people rather than the general population. The average WTP per person per month was 16.67 Ghana cedis per month (0.56 Ghana cedi per day; roughly US 14 cents) or 200.04 Ghana cedis or US\$51.96 per year. Aggregating for the estimated close to one-quarter of a million $(249,144)$ public weather services users in formal services sector of Accra, we get the total economic value of US $\$ 12,945,134$. This aggregate economic value, based on only the users of public weather services in the formal services sector of Accra, who constitute just about $2.1 \%$ of the total work force of Ghana, is over four times the value of the annual budget provided by the Government of Ghana to GMet of GHC12,085,012 (US\$2,810,467) in 2016 [49]. 
The economic value of the public weather services established by the contingent valuation method was shown to be influenced by the overall usefulness of the services, the use rate intensity, and whether the person used it for both consumption purposes and business/work activities. As expected, those using the public weather services, for both consumption and work activities, valued the services much more than those who used the services only as consumption goods for their day-to-day living. The results dealing with the economic value of the public weather reflecting the intensity of their use and their perceived quality are largely consistent with other works in the literature [31] [34] [36].

An area of improvement suggested by respondents to GMet is for the Agency to provide regular updates of weather information and warnings possibly on an hourly basis through the publicly-owned and privately-owned mass media. The regular broadcasts of updates of weather are necessary given the rapidly-changing nature of the weather that had been observed in Ghana over the last decade where severe downpour of rain and major windstorm had suddenly occurred defying the expectations of many older people with a certain appreciation of the long weather phenomena in certain periods of the year. The argument that meteorological conditions in Ghana are constant given the nature of the tropical conditions appear less valid; dissemination of weather warnings and other meteorological information need to go beyond the aviation industry which is particularly well served by GMet.

Respondents also wanted the public weather services to be improved in the form of their presentation in simple easily-understood language and for the incorporation of adequate warning times for users to take adequate protection against the relevant natural hazards. Further, respondents requested the public weather services to be more locality-specific, through the production of district-based weather forecasts or forecasts for specific smaller-sized geographical zones was requested. For example, weather forecasts for the Mole National Park in the Northern Region which runs regular safari-type trips and tours would be useful to local and foreign tourists.

In concluding this paper, despite the limitation of the study inherent in its small size, we focus on the policy implications concerning the ability to pay for meteorological services, the widening income distribution of the population, and the transaction costs involved in actually collecting monies to finance a public agency which has been shown to be producing economically-valuable services. The ability and willingness to pay for public weather services by formal services sector workers in Accra is realistic given that most of these workers would be in the lower-middle-income to upper-middle-income groups of Ghanaians. Using data on income classes based on the 2012/2013 Ghana Living Standards Survey 6 results published by the Ghana Statistical Service, and those also established by the Economist Magazine of London, Great Britain [50] [51], the proportion of people in Ghana, classified as middle class, that is those earning between 10 United States (US) dollars to 50 US dollars per day, increased from $8.5 \%$ in $2005 / 2006$ to about $13.5 \%$ in $2012 / 2013$. The proportion of people living below 
the poverty line (US $\$ 1.83$ per day) declined from $31.9 \%$ in $2005 / 2006$ to $24.2 \%$ in 2012/2013 [50] [51]. However, the proportion of people classified as lowincome, that is those earning between US $\$ 1.83$ per day and US $\$ 10$ per day, increased from about $59.0 \%$ in 2005/2006 to about $61.5 \%$ in 2012/2013.

Overall, income inequality in Ghana has worsened with the Gini coefficient, a measure of income inequality, increasing from 41.9 in 2005/2006 to 42.3 in $2012 / 2013$, above the widely accepted tolerance limit of 40.0 for developing countries. Hence, many citizens in the low-income groups, especially those in the informal sector of the economy, which accounts for about $86.2 \%$ of all workers (refer to Table 1) [1], may not be able to pay for public weather services including warnings. The State needs to properly finance the GMet to allow it to deliver higher quality meteorological services to serve and reach all aspects of the population especially for weather warnings and information on natural hazards.

The transaction costs in directly collecting monies from individuals for public weather services would be enormous and would outweigh the revenues raised. Hence the government must adequately finance GMet to deliver improved and higher quality public weather services to serve the population through general tax revenues. Adequate financing of GMet by the Government would be in line with the Ghana Meteorological Act, 2004 Act 682, which re-established the Ghana Meteorological Agency as a successor to the Meteorological Services Department originally established by the British Colonial Government in 1937 [52]. Act 682 mandates the establishment of a National Meteorological Fund to be funded by the State that is adequate in size for GMet to undertake the public responsibilities assigned to the Agency under the Act.

\section{Acknowledgements}

We express our appreciation to the Office of Research, Innovation and Development, University of Ghana, Legon, Accra for financing the study and the Ghana Meteorological Agency for providing various forms of logistic support to undertake the study. Part of this paper was included in the keynote speech delivered by the senior author at the International Workshop on Climate Information for African Legislators and Members of Parliament held at the M Plaza Hotel, Accra, Ghana on 12 December 2016 [45].

\section{References}

[1] Ghana Statistical Service (GSS) (2013) 2010 National Population and Housing Census: Analytical Report. GSS, Accra.

[2] Buah, F.K. (1998) A History of Ghana. MacMillan Education, London.

[3] Davidson, B. (1972) History of Africa. Spring Books, London.

[4] Ward, W.E.F. (1948) A History of the Gold Coast. George Allen and Unwin, London.

[5] Anaman, K.A. (2006) Determinants of Economic Growth in Ghana. Monograph No. 14, Institute of Economic Affairs, Accra.

[6] Anaman, K.A., Agyei-Sasu, F. and Okyere, C.Y. (2011) Report of the 2011 Survey 
on Monitoring the Paris Declaration on Aid Effectiveness for Ghana: Country Report. Report Submitted to the Ministry of Finance and Economic Planning, Accra, Ghana and the Organisation for Economic Cooperation and Development, Paris, 53 p.

[7] Anaman, K.A. (2016) Impact of Democratic Political Transition on the Economy of Ghana. In: Kwame A, N., Ed., Issues in Ghana's Electoral Politics, Council for the Development of Social Science Research in Africa, Dakar, 135-152.

[8] Anaman, K.A. and Agyei-Sasu, F. (2012) Impact of Democratic Political Transition on the Performance of Business Firms in Ghana. Economic Papers. A Journal of Applied Economics and Policy, 31, 391-400. https://doi.org/10.1111/j.1759-3441.2011.00151.x

[9] Anaman, K.A. (2015) Assessment of the Economic and Social Benefits of Meteorological Services in Ghana. Research Proposal Submitted to Office of Research, Innovation and Development, University of Ghana, Legon, Accra, 18 p.

[10] Energy Commission of Ghana (2015) National Energy Statistics 2005 to 2014. Energy Commission of Ghana, Accra.

[11] Government of Ghana (2006) Growth and Poverty Reduction Strategy (GPRS II). National Development Planning Commission, Accra.

[12] Government of Ghana (2010) Ghana Shared Growth and Development Agenda (GSGDA). 2010-2013 Policy Framework. Volume 1, National Development Planning Commission, Accra.

[13] Aremu, J.O. and Ajayi, T.A. (2014) Expulsion of Nigerian Immigrant Community from Ghana in 1969: Causes and Impact. Developing Country Studies, 4, 176-186.

[14] Ghana Statistical Service (GSS) (2017) Provisional 2016 Annual Gross Domestic. April 2017 Edition, GSS, Accra.

[15] Chapman, D. (1994) Natural Hazards. Oxford University Press, London.

[16] Cutter, S. and Finch, C. (2007) Temporal and Spatial Changes in Social Vulnerability to Natural Hazards. Proceedings of the National Academy of Social Sciences of the United States of America, 105, 2301-2306. https://doi.org/10.1073/pnas.0710375105

[17] Noy, I. (2009) The Macroeconomic Consequences of Disasters. Journal of Development Economics, 88, 221-231. https://doi.org/10.1016/j.jdeveco.2008.02.005

[18] Cavallo, E.A. and Noy, I. (2010) The Economics of Natural Disasters: A Survey. Inter-American Development Bank, Washington DC.

[19] Benson, C. and Clay, E.J. (2000) Developing Countries and the Economic Impacts of Natural Disasters. In: Alcira, K. and Arnold, M., Eds., Managing Disaster Risk in Emerging Economies, World Bank Publications, Washington DC, 11-21.

[20] Skidmore, M. and Toya, H. (2002) Do Natural Disasters Promote Long-Run Growth? Economic Inquiry, 40, 664-687. https://doi.org/10.1093/ei/40.4.664

[21] McEntire, D.A. and Mathis, S. (2007) Comparative Politics and Disasters: Assessing Substantive and Methodological Contributions. In: McEntire, D.A., Ed., Disciplines, Disasters and Emergency Management. The Convergence and Divergence of Concepts, Issues and Trends from the Research Literature. Charles C. Thomas Publisher, Springfield, 178-195.

[22] Vogel, C. and O'Brien, K. (2006) Who Can Eat Information? Examining the Effectiveness of Seasonal Climate Forecasts and Regional Climate-Risk Management Strategies. Climate Research, 33, 111-122. https://doi.org/10.3354/cr033111

[23] Davis, G.B. and Olson, M.H. (1985) Management Information Systems, Conceptual Foundations, Structure and Development, McGraw Hill, New York. 
[24] Anaman, K.A. and Lellyett, S.C. (1996) Producers' Evaluation of an Enhanced Weather Information Service for the Cotton Industry in Australia. Meteorological Applications, 3, 113-125. https://doi.org/10.1002/met.5060030202

[25] Mitchell, V.-W. and Volking, Y.E. (1993) Analysing the Quality of Management Information: A Suggested Framework. Management Decision, 31, 2-19. https://doi.org/10.1108/00251749310047115

[26] Anaman, K.A., Thampapillai, D.J., Henderson-Sellers, A., Noar, P.F. and Sullivan, P.J. (1995) Methods for Assessing the Benefits of Meteorological Services in Australia. Meteorological Applications, 2, 17-29. https://doi.org/10.1002/met.5060020104

[27] Abelson, P. (1996) Project Appraisal and Valuation of the Environment. Macmillan Press Limited, London. https://doi.org/10.1057/9780230374744

[28] Anaman, K.A., Lellyett, S.C., Drake, L., Leigh, R.J., Henderson-Sellers, A., Noar, P.F., Sullivan, P.J. and Thampappillai, D.J. (1998) Benefits of Meteorological Services: Evidence of Recent Research in Australia. Meteorological Applications, 5, 103-115. https://doi.org/10.1017/S1350482798000668

[29] Thampapillai, D.J. (2002) Environmental Economics: Concepts, Methods, and Policies. Oxford University Press, Melbourne.

[30] Asafu-Adjaye, J. (2005) Environmental Economists for Non-Economists, Second Edition. World Scientific Press, Singapore. https://doi.org/10.1142/5727

[31] World Meteorological Organization (WMO) (2015) Valuing Weather and Climate: Economic Assessment of Meteorological and Hydrological Services, WMO, Geneva.

[32] Hotelling, H. (1949) Letter Quoted by Prewitt, R.E. in "Economic Study of the Monetary Evaluation of Recreation in National Parks". United States Department of Interior, Washington DC.

[33] Clawson, M. (1959) Methods of Measuring the Demand for and Value of Outdoor Recreation. Reprint, No.10, Resources for the Future, Washington DC.

[34] Anaman, K.A. and Lellyett, S.C. (1996) A Contingent Valuation Study of the Public Weather Service in the Sydney Metropolitan Area. Economic Papers. A Journal of Applied Economics and Policy, 15, 64-77. https://doi.org/10.1111/j.1759-3441.1996.tb00123.x

[35] Leigh, R.J. (1995) Economic Benefits of Terminal Aerodrome Forecasts at Sydney Airport, Australia. Meteorological Applications, 2, 239-247. https://doi.org/10.1002/met.5060020307

[36] Leigh, R.J., Drake, L. and Thampapillai, D.J. (1998) An Economic Analysis of Terminal Aerodrome Forecasts with Special Reference to Sydney Airport. Journal of Transport Economics and Policy, 32, 377-392.

[37] Anaman, K.A., Lellyett, S.C. and Avsar, G.S. (2000) Assessing the Effect of Aviation Weather Forecasts on Fuel Expenditures of an International Airline. International Journal of Transport Economics, 27, 257-277.

[38] Campos, M., Drake, L. and Anaman, K.A. (1999) Impact of Tropical Cyclones Warning Information on Incomes of Commercial Tourist Accommodation Operators Along the Queensland Coast. Economic Analysis and Policy, 29, 185-193.

[39] Von Gruenigen, S., Willemse, S. and Frei, T. (2014) Economic Value of Meteorological Services to Switzerland's Airlines: The Case of TAF at Zurich Airport. Weather, Climate, and Society, 6, 264-272. https://doi.org/10.1175/WCAS-D-12-00042.1

[40] Anaman, K.A., Quaye, R. and Owusu-Brown, B. (2017) Benefits of Aviation Weather Services: A Review of International Literature. Research in World Econo$m y, 8,45-58$. https://doi.org/10.5430/rwe.v8n1p45 
[41] Anaman, K.A. and Lellyett, S.C. (1996) Assessment of the Benefits of an Enhanced Weather Information Service for the Cotton Industry in Australia. Meteorological Applications, 3, 127-135. https://doi.org/10.1002/met.5060030203

[42] Anaman, K.A. and Lellyett, S.C. (1997) Evaluation of Use and Benefits of Public Weather and Climate Services by the Mining Industry in Queensland. Queensland Government Mining Journal, 98, 56-61.

[43] Leviäkangas, P. and Hautala, R. (2009) Benefits and Value of Meteorological Information Services-The Case of the Finnish Meteorological Institute. Meteorological Applications, 16, 369-379. https://doi.org/10.1002/met.135

[44] Ewent Consortium (2012) Economic Value of Weather Forecasts on Transportation-Impacts of Weather Forecasts Quality Developments to the Economic Effects of Severe Weather. http://www.ewent.ttt.fi

[45] Anaman, K.A. (2016) Economic Benefits of Meteorological Services: Theory and Empirical Applications with Examples from Ghana and Australia. Paper Presented as the Keynote Speaker at the Workshop on Climate Information for Legislators and Members of Parliament in Africa, 12 December 2016, Accra.

[46] Amegnaglo, C.J., Anaman, K.A., Mensah-Bonsu, A., Onumah, E.E. and Gero, F.A. (2017) Contingent Valuation Study of the Benefits of Seasonal Climate Forecasts for Maize Farmers in the Republic of Benin, West Africa. Climate Services, 11 p. (In Press) https://doi.org/10.1016/j.cliser.2017.06.007

[47] Ghana Statistical Service (GSS) (2013) 2010 National Population and Housing Census: Regional Analytical Report for the Greater Accra Region. Chapter 9, GSS, Accra.

[48] De Vaus, A. (2002) Surveys in Social Research. 5th Edition, Allen and Unwin, London.

[49] Ghana Meteorological Agency (2017) Ghana Meteorological Agency Budget for 2016 based on Personal Communication with the Director-General of GMet dated 27 June 2017. Ghana Meteorological Agency, Accra.

[50] Ghana Statistical Service (2014) Ghana Living Standards Survey Round 6 (GLSS) 6 Main Report. GSS, Accra.

[51] Economist Magazine (2015) Africa's Middle Class Few and Far Between. African Are Mainly Rich or Poor; But Not Middle Class. That Should Worry Democrats. Economist Magazine, London.

[52] Government of Ghana (2014) Ghana Meteorological Act 2004, Act 682. Government of Ghana, Accra. 
Submit or recommend next manuscript to SCIRP and we will provide best service for you:

Accepting pre-submission inquiries through Email, Facebook, LinkedIn, Twitter, etc. A wide selection of journals (inclusive of 9 subjects, more than 200 journals)

Providing 24-hour high-quality service

User-friendly online submission system

Fair and swift peer-review system

Efficient typesetting and proofreading procedure

Display of the result of downloads and visits, as well as the number of cited articles Maximum dissemination of your research work

Submit your manuscript at: http://papersubmission.scirp.org/

Or contact me@scirp.org 